\title{
WPŁYW ZMIENNOŚCI NATĘŻEŃ RUCHU NA OCENE UCIĄŻLIWOŚCI HAŁASU DROGOWEGO
}

\begin{abstract}
Czas przeprowadzania pomiarów wyrywkowych (okres w roku i dobie) determinuje dokładność szacowania poziomu hałasu. Dlatego też istnieje konieczność określenia ujednoliconych procedur wyznaczania miarodajnych wartości parametrów ruchu do obliczeń $\mathrm{L}_{\mathrm{pAeq}} \mathrm{w}$ szczególności w odniesieniu do metody próbkowania. W artykule przedstawiono możliwy wpływ krótkotrwałych pomiarów ruchu i hałasu na ocenę poziomu hałasu drogowego.
\end{abstract}

Słowa kluczowe: poziom hałasu, ruch drogowy, wahania ruchu, pomiary ruchu

\section{Wprowadzenie}

Uciążliwości hałasu są jednym z większych problemów ochrony środowiska w budownictwie drogowym. Powoduje to konieczność przeznaczania coraz większych środków na zabezpieczenia akustyczne otoczenia istniejących i nowo projektowanych odcinków drogowych. Ze względu na niewielką zajętość terenu i skuteczność najczęściej stosowanymi środkami ochrony przed hałasem drogowym są ekrany akustyczne. Decyzje o konieczności stosowanie kosztownej ochrony akustycznej podejmuje się często na podstawie krótkotrwałych pomiarów hałasu w przypadku dróg istniejących lub częściowych danych ruchowych na podstawie, których sporządza się prognozę oddziaływania hałasu drogowego na otoczenie. W analizach uciążliwości hałasu od ruchu drogowego do określania jego poziomu u źródła $\left(\mathrm{L}^{\mathrm{p}}{ }_{\text {Aeq }}\right)$, przyjmuje się jako natężenie miarodajne średnie godzinowe natężenie $\mathrm{w}$ dwóch okresach w ciągu doby (pora dzienna w godzinach 6:00-22:00 oraz nocna 22:00-6:00).

Niestety rozporządzenia $[1,2]$ nie podają żadnych wytycznych w jakich okresach powinno wykonywać się pomiary hałasu oraz towarzyszące im pomia-

\footnotetext{
1 Autor do korespondencji/corresponding author: Malwina Spławińska, Politechnika Krakowska, Katedra Budowy Dróg i Inżynierii Ruchu, ul. Warszawska 24, 31-155 Kraków, 126282323 , msplaw@pk.edu.pl

${ }^{2}$ Krystian Woźniak, Politechnika Krakowska, Katedra Budowy Dróg i Inżynierii Ruchu, ul. Warszawska 24, 31-155 Kraków, 12 6282158, kwozniak@pk.edu.pl
} 
ry natężenia ruchu i średniej chwilowej prędkości pojazdów. Jednocześnie na mocy rozporządzenia [2] dopuszcza się pomiar poziomu hałasu z wykorzystaniem czterech metod, w tym metody próbkowania budzącej spore zastrzeżenia co do jakości wyników. W metodzie tej równoważny poziom hałasu A powinno wyznaczać się na podstawie pomiarów w reprezentatywnych przedziałach czasu ustalonych z uwzględnieniem analizy dobowego rozkładu poziomu hałasu. Brak jednak wskazań co do sposobu określania tych przedziałów (podaje się jedynie że należy dokonać grupowania przedziałów czasu, podczas których wartość równoważnych poziomów hałasu nie różnią się więcej niż 3 decybele). Liczbę pomiarów w każdym reprezentatywnym przedziale pomiarów $t_{k}$ uzależniono od rozstępu $\mathrm{R}$ między skrajnymi wynikami pomiarów. Podstawowym interwałem rejestracyjnym jest 10 minut. Oczywistym wydaje się, że czas przeprowadzania pomiarów wyrywkowych (dzień tygodnia, miesiąc w roku, godziny w dobie) determinują dokładność szacowania poziomu hałasu. Dlatego też istnieje konieczność określenia ujednoliconych procedur wyznaczania miarodajnych wartości parametrów ruchu do obliczeń $\mathrm{L}^{\mathrm{p}}{ }_{\text {eeq }}$. Brak takiej procedury powoduje duże ryzyko mało wiarygodnych ocen rzeczywistego wpływu ruchu na hałas w otoczeniu i tym samym możliwe błędy czy niedoszacowania/przeszacowania w opracowaniach będących podstawą do podjęcia decyzji np. o konieczności budowy ekranów akustycznych. Celem publikacji jest przedstawienie możliwego wpływu krótkotrwałych pomiarów ruchu i hałasu na ocenę zagrożenia hałasem drogowym. Problem analizowany w referacie jest wynikiem stosowania obowiązującego rozporządzenia [2], które umożliwia pomiar poziomu hałasu przy zastosowaniu jednej z czterech metod. Na podstawie własnych badań oraz analiz opracowań i wyników realizowanych pomiarów w ramach między innymi ocen porealizacyjnych, pomiarów realizowanych w ramach ocen oddziaływania inwestycji na środowisko zauważa się możliwy wpływ metody pomiarowej na końcową ocenę uciążliwości hałasu drogowego (zagrożenia hałasem wyższym od poziomu dopuszczalnego). Wpływ ten wiąże się głównie ze zmiennością ruchu w czasie. Autorzy nie dotarli do innych pozycji bibliografii oprócz wykazanych, które poruszałyby problem opisany w referacie tj. konsekwencję wyboru metody pomiarowej w odniesieniu do możliwych niepewności w ocenie poziomu hałasu i w konsekwencji oceny jego uciążliwości w otoczeniu drogi.

\section{Baza danych i metoda badań}

W badaniach zmienności natężeń ruchu, w różnych okresach, wykorzystano dane pochodzące $\mathrm{z}$ ciągłego pomiaru ruchu prowadzonego $\mathrm{w}$ roku 2010 na zamiejskich drogach krajowych (stacje zarządzane przez prywatną firmę Traxelektronik [3]). Zakres danych obejmuje rejestrację liczby pojazdów w interwałach 10 minutowych, w podziale na dwie kategorie pojazdów (o długości do i powyżej $5 \mathrm{~m}$ ) w 5 zakresach prędkości. Ponadto rejestruje się prędkość maksymalną i średnią na każdym z pasów. Ze względu na wykazane w [4] duże 
zróżnicowanie wartości poziomu hałasu, wyznaczonego przy uwzględnieniu udziału pojazdów ciężkich w odniesieniu do doby lub do poszczególnych okresów doby (do 3,6 dB), analizy prowadzono w przekroju drogi w podziale na pojazdy lekkie i ciężkie. $Z$ analiz, ze względu na odbiegające wartości natężeń od wartości przeciętnych (zidentyfikowane na podstawie obserwacji szeregów czasowych natężeń dobowych, godzinowych i dziesięciominutowych w roku), usunięto dni ustawowo wolne od pracy oraz bezpośrednio z nimi związane.

$\mathrm{W}$ celu oceny wpływu zmienności ruchu na poziom hałasu $\mathrm{w}$ otoczeniu dróg posłużono się metodą pośrednią, wykorzystując duże i dokładne zbiory danych o ruchu i jego parametrach (brak było danych w odniesieniu do pomierzonych wartości poziomów hałasu $\mathrm{L}_{\text {Aeq }}[\mathrm{dB}]$ ). Podejście to jest usankcjonowanie $\mathrm{w}$ [2] i stanowi jedną z możliwych do zastosowania metod szacowania hałasu drogowego - metodę obliczeniową. Metoda pośrednia polegała na wykorzystaniu danych ruchowych do wyznaczenia poziomu hałasu metodą obliczeniową, zweryfikowaną w innych badaniach autorów [5,6]. Do wyznaczenia podstawowego poziomu hałasu drogowego $\left(\mathrm{L}^{\mathrm{p}}{ }_{\text {Aeq }}\right.$ ) wykorzystano metodę Radosza [6] (wzór 2).

$$
L_{\text {Aeqtk }}=10 \log \left[\frac{1}{m} \sum 10^{0,1 L_{A k i}}\right][d B]
$$

gdzie:

$\mathrm{L}_{\text {Aeqtk }}$ - średnia wartość poziomu hałasu A

$\mathrm{t}_{\mathrm{k}},-$ reprezentatywny przedział czasu pomiaru poziomu hałasu A

$\mathrm{L}_{\mathrm{Aki}}$ - wartość poziomu hałasu zmierzonego $\mathrm{w}$ reprezentatywnym przedziale czasu $t_{k}$, w decybelach $[\mathrm{dB}]$. Ze względu na brak pomiarów rzeczywistych $\mathrm{L}_{\mathrm{Aki}}$ wyznaczono na podstawie wzoru 2 ,

$\mathrm{m}$ - liczba pomiarów poziomów hałasu w reprezentatywnym przedziale czasu $t_{k}$.

$$
L_{\text {Aeq }}^{p}=9,7 \log Q+4,2 \log v+0,11 u_{c}+33,4[d B]
$$

gdzie:

$\mathrm{L}^{\mathrm{p}}{ }_{\text {Aeq }}$ - podstawowy poziom hałasu drogowego w punkcie odniesienia, $\mathrm{tj}$. w odległości $\mathrm{d}=10 \mathrm{~m}$ od krawędzi jezdni i na wysokości $\mathrm{H}=1,2 \mathrm{~m}$ ( $p=D$ odnosi się do pory dnia - godziny 6:00 - 22:00 natomiast $p=N$ do pory nocy - godziny 22:00-6:00),

$\mathrm{Q}$ - natężenie ruchu w obu kierunkach $[\mathrm{P} / \mathrm{h}]$,

$\mathrm{v}$ - chwilowa prędkość średnia potoku[km/h],

$\mathrm{u}_{\mathrm{c}}-$ udział pojazdów ciężkich [\%]. 


\section{Określenie okresów o najmniejszej zmienności natężeń ruchu w roku i dobie}

W celu określenia okresów o najmniejszej zmienności natężenia ruchu w roku i dobie, wyznaczono współczynnik zmienności natężeń 10 minutowych w miesiącach $\mathrm{w}$ roku, dniach $\mathrm{w}$ tygodniu i godzinach $\mathrm{w}$ dobie (w podziale na porę dnia i nocy) - $\varepsilon$ (wzór 3) wraz z rankingiem. Słuszność takiego podejścia została potwierdzona we wcześniejszych pracach autorów [7, 8]. Ze względu na duże zróżnicowanie natężeń, analizy zmienności rocznej prowadzono najpierw oddzielnie dla każdego z dni tygodnia w każdym z miesięcy a następnie łącznie dla wszystkich dni tygodnia w danym miesiącu (pozwoliło to na stłumienie wartości odstających).

$$
\varepsilon=\left(\frac{\sigma}{\bar{y}}\right) \times 100[\%]
$$

gdzie:

$\varepsilon$ - współczynnik zmienności badanej cechy ruchu,

$\sigma$ - odchylenie standardowe badanej cechy ruchu,

$\bar{y}$ - wartość przeciętna badanej cechy ruchu (średnie natężenie dziesięciominutowe danego dnia tygodnia/miesiąca w roku, średnie natężenie dziesięciominutowe $\mathrm{w}$ danej porze dnia w odniesieniu do danego dnia tygodnia).

W przypadku dni tygodnia i miesięcy w roku liczba 7 i 12 odpowiada odpowiednio dniu i miesiącowi $\mathrm{z}$ największą wielkością $\varepsilon$ a 1 z najmniejszą. W przypadku pory dnia liczba 96 i 48 odpowiada okresowi z największą wielkością $\varepsilon$ odpowiednio w okresie dnia i nocy a 1 z najmniejszą. Przykładowe wyniki przedstawiono na rys. 1 (pora nocy na przykładzie środy). Wartość współczynnika zmienności $\varepsilon$ badanej cechy ruchu, zależy w dużym stopniu od struktury rodzajowej oraz pory dnia, co ma znaczący wpływ na wybór okresu pomiarowe-

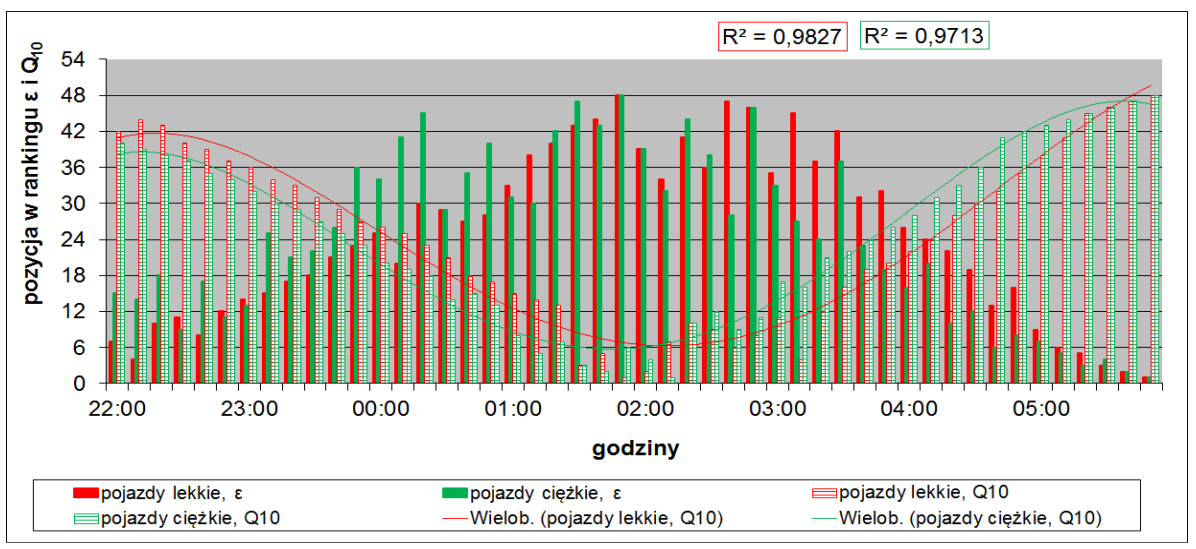

Rys 1. Ranking $\varepsilon$ dla natężeń 10 minutowych

Fig. 1. Ranking of $\varepsilon$ for traffic volume 10 minutes 
go. Z uwagi na ograniczenia tekstu w dalszej części odniesiono się wyłącznie do pojazdów ciężkich, mających decydujący wpływ na poziom hałasu. W odniesieniu do poszczególnych dni tygodni uzyskano współczynnik zmienności $\varepsilon$ : dzień - najmniejszy dla wtorku, środy i piątku; największy dla soboty i niedzieli; noc najmniejszy dla poniedziałku, środy i czwartku; największy dla soboty i niedzieli. W odniesieniu do poszczególnych miesięcy w roku uzyskano współczynnik zmienności $\varepsilon$ : dzień - najmniejszy dla miesięcy VI - X; największy dla I, III, XI, XII; noc - najmniejszy dla miesięcy IV* (usunięcie $\mathrm{z}$ analiz 10 dni ze względu na nietypowe zmienności natężeń wynikające $\mathrm{z}$ dni ustawowo wolnych od pracy - wynik niepewny), VI - IX, XI; największy dla I - III. W odniesieniu do poszczególnych okresów dziesięciominutowych w dniu lub nocy uzyskano współczynnik zmienności $\varepsilon$ : dzień - najmniejszy w godzinach 7:30 - 16:00; największy w godzinach 6:00 - 7:10, 16:50 - 22:00; noc - najmniejszy w godzinach 22:00 - 23:30, 3:50 - 6:00; największy w godzinach 23:50 - 3:10.

W celu sprawdzenia jak wielkość natężenia ruchu wpływa na jego zróżnicowanie, wykonano analogiczny jak dla współczynnika zmienności, ranking dla średnich natężeń dziesięciominutowych w okresie dnia i nocy $\left(\mathrm{Q}_{10}\right.$ - rysunek 1). W celu łatwiejszej interpretacji wyników, do wykresów dodano linię trendu (wielomian stopnia 4) wraz ze współczynnikiem determinacji $\mathrm{R}^{2}$. Dla pojazdów ciężkich, dla pory dnia największe wartości natężeń uzyskano w godzinach 10:00 - 17:00 a najmniejsze 6:00 - 8:00 i 17:00 - 22:00. W przypadku pory nocnej największe wartości natężeń uzyskano w godzinach 22:00 - 00:00 i 4:30 - 6:00 a najmniejsze 00:30 - 3:00. Wynika $z$ tego, że największe wielkości natężeń ruchu pokrywają się z okresami o najmniejszym zróżnicowaniu (najmniejsza wartość $\varepsilon$ ), a najmniejsze wartości odpowiadają okresom o największym zróżnicowaniu (największa wartość $\varepsilon$ ). Można zatem wnioskować, że wielkość natężeń ruchu ma wpływ na wybór optymalnego okresu pomiarowego.

\section{Analiza wpływu okresu wykonywania pomiaru metodą prób- kowania (zgodnie $z$ [2]) na poziom hałasu}

W celu ustalenia najmniej korzystnego przypadku, analizy przeprowadzono w dwóch wariantach tj. wyselekcjonowanie $m$ okresów dziesięciominutowych $\left(\mathrm{Q}_{10}\right)$ dających ekstremalne wartości poziomu hałasu w godzinie $\mathrm{L}_{\text {Aki }}$ (najmniejsze i największe). Przy takim podejściu można uzyskać wartości najbardziej odbiegające od wartości średniej i jednocześnie najmniej zróżnicowane w reprezentatywnym przedziale czasu (najmniejszy rozstęp między skrajnymi wynikami). Analizy ograniczono do dni poniedziałek - piątek (od 6:00 w poniedziałek do 6:00 w sobote) i miesięcy V - X (pozostałe dni i miesiące zgodnie ze wcześniejszymi ustaleniami są niekorzystnym okresem przeprowadzania pomiarów ruchu). Ponieważ wartość równoważnych poziomów hałasu w kilku sąsiednich godzinach (w zdecydowanej większości przypadków), nie różni się o więcej niż $3 \mathrm{~dB}$, analizy prowadzono w odniesieniu do jednego reprezentatywnego przedziału czasu. Ponadto, w większości analiz uzyskano dla okresu dnia rozstęp $\mathrm{R}$ 


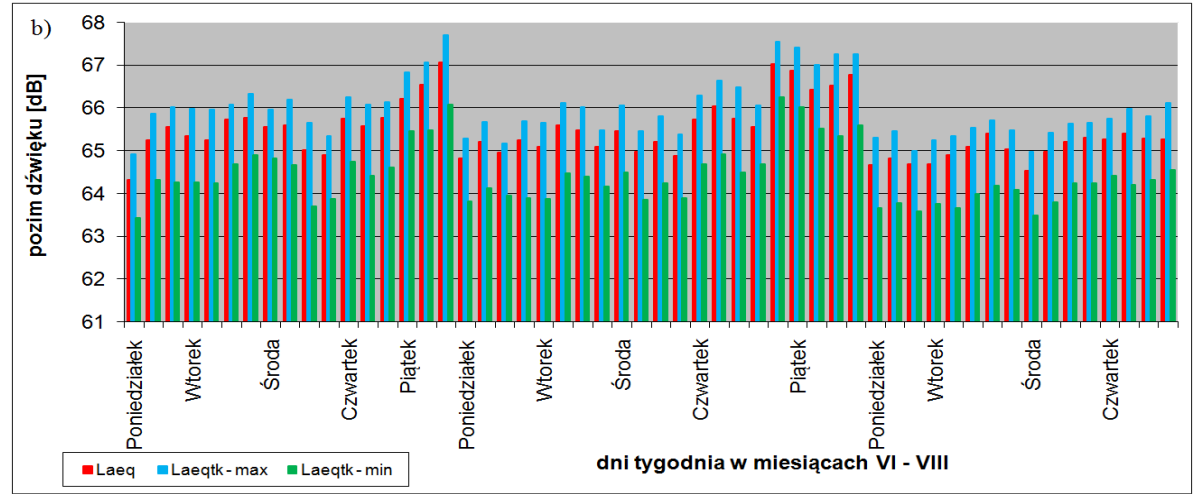

Rys. 2. Poziom hałasu LpAeq i średnia wartość LAeqtk w porze nocy

Fig. 2. The noise level LpAeq and the average value of LAeqtk at the night time

między skrajnymi wynikami pomiarów mniejszy od dwóch, a dla okresu nocy od czterech, dlatego też liczbę pomiarów m przyjęto odpowiednio jako 3 i 4 [2]. Na rysunku 2 przedstawiono, przykładowo dla DK2, Biała Podlaska, uzyskaną wartość $\mathrm{L}^{\mathrm{p}}{ }_{\text {Aeq }} \mathrm{W}$ dniach tygodnia od poniedziałku do piątku w miesiącach VI - VIII oraz średnią wartość $\mathrm{L}_{\text {Aequtk }}$ uzyskaną $\mathrm{z}$ pomiaru metodą próbkowania (w grupie największych i najmniejszych możliwych wartości $\mathrm{L}_{\mathrm{Aki}} \mathrm{w}$ godzinie).

W celu określenia wpływu zmienności natężeń $\mathrm{Q}_{10}$ na poziom hałasu, uzyskane wartości $\mathrm{L}_{\text {Aeqtk }}$ porównano $\mathrm{z}$ wartościami $\mathrm{L}^{\mathrm{p}}{ }_{\text {Aeq }}$ (wyznaczonymi na podstawie pomiarów dobowych będących analogią do pomiarów ciągłych hałasu) i wyznaczono ich bezwzględną różnicę (im mniejsza różnica tym większa dokładność szacunków poziomu hałasu na podstawie pomiarów wyrywkowych). Największa $\mathrm{z}$ wartości dla każdego z dnia tygodnia (przy kilku reprezentantach np. poniedział$\mathrm{ku}$, przy uwzględnieniu zbiorów $\mathrm{z}$ największymi wartościami $\mathrm{L}_{\mathrm{Aki}}$ i najmniejszymi) w danym miesiącu, posłużyła do dalszych analiz. Ze względu na zbliżone wielkości różnic w dniach od poniedziałku do piątku, połączono je poprzez uśrednienie a także miesiące VI - VIII i X (jedynie w przypadku VIII, ze względu na zdecydowanie odstające wartości, $\mathrm{z}$ analiz usunięto piątki). W toku dalszych analiz ze względu na podobieństwo różnic na odcinkach dróg charakteryzujących się zbliżonymi wartościami natężeń ruchu, podzielono dane ze względu na wielkość SDR $(\mathrm{SDR} \leq 5000 \mathrm{P} / \mathrm{d}$ - grupa $1 ; 5000<\mathrm{SDR} \leq 10000 \mathrm{P} / \mathrm{d}$ - grupa $2 ; \mathrm{SDR}>10000 \mathrm{P} / \mathrm{d}$ grupa 4). Podejście to jest zgodne z przesłankami literaturowymi [7]. Ponadto w grupie dróg o wielkości SDR w zakresie 5000 - 10000 P/d wydzielono drogi o bardzo dużym udziale pojazdów ciężkich w miesiącach VI - X (około 50\% grupa 3). Uzyskane wyniki oceny różnic $\mathrm{L}_{\text {Aeq }}^{\mathrm{p}} \mathrm{i} \mathrm{L}_{\text {Aeqtk }}$ przedstawiono na rysunku 3.

$\mathrm{Z}$ przeprowadzonych analiz wynika, że okres analizy wpływa na dokładność szacowania poziomu hałasu oraz że wpływ ten jest różny w zależności od wielkości natężeń ruchu oraz udziału pojazdów ciężkich. Przy uwzględnieniu grup dróg, największą dokładność uzyskano w przypadku dróg charakteryzujących się wartością 


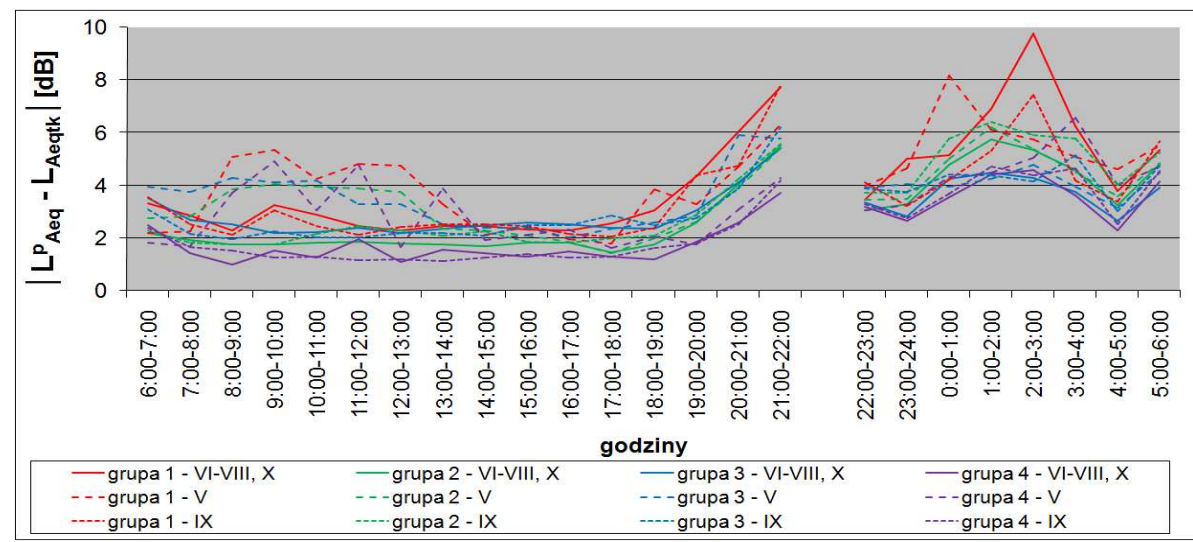

Rys. 3. Średnia bezwzględna różnica pomiędzy wartością LpAeq i LAeqtk, w zależności od okresów pomiarów i grupy dróg

Fig. 3. The average absolute difference between the value of LpAeq and LAeqtk, depending on the measurement periods and road groups

SDR > $10000 \mathrm{P} / \mathrm{d}$ (średnia wartość $\mathrm{Q}_{10} \mathrm{w}$ porze dnia 170P/h i 40P/h dla nocy), a najmniejszą w przypadku dróg o $\mathrm{SDR} \leq 5000 \mathrm{P} / \mathrm{d}$ (średnia wartość $\mathrm{Q}_{10} \mathrm{w}$ porze dnia $45 \mathrm{P} / \mathrm{h}$ i 10P/h dla nocy). Różnica oszacowanego poziomu hałasu pomiędzy miesiącami VIVIII i X, wynosi od 0,4 do 4,0 dB w przypadku dnia oraz od 0,3 do 5,2 dB w nocy.

\section{Podsumowanie}

Na podstawie rankingu współczynników zmienności natężeń 10 minutowych w roku i dobie (w podziale na porę dnia i nocy) jak również największej uzyskanej dokładności szacowania poziomu hałasu przy wykorzystaniu metody próbkowania, wyznaczono najkorzystniejsze okresy wykonywania pomiarów ruchu. Są nimi: miesiące VI - X; dni tygodnia wtorek - piątek; godziny 8:00 - 17:00 (pora dnia) oraz 22:00 - 24:00 i 4:00 - 5:00 (pora nocy). W przypadku danych pochodzących z tego okresu uzyskano nie tylko największą dokładność szacowania poziomu hałasu, ale także najmniejsze zróżnicowanie kolejnych dziesięciominutowych natężeń ruchu bez względu na rodzaj pojazdów. Najmniej korzystnymi okresami przeprowadzania pomiarów są: miesiące I - IV i XI - XII ; dni tygodnia sobota i niedziela; godziny 6:00 - 7:00 i 17:00 - 22:00 (pora dnia) oraz 0:00 - 3:00 i 5:00 - 6:00 (pora nocy). Wyniki badań i analiz wskazują na konieczność dokładnego rozpoznania zmienności ruchu w dobie przed wyborem jednej z czterech metod pomiaru hałasu drogowego [2]. Analizując zakres zmienności poziomu hałasu w ciągu doby stwierdzono, że określanie poziomu hałasu w ciągu dnia lub nocy na podstawie krótkotrwałych pomiarów hałasu lub na podstawie obliczeń poziomu hałasu bazujących na wyrywkowych danych ruchowych może prowadzić do dużych błędów oszacowań, wynoszących w skrajnych przypadkach nawet 8dBA. Jest to bardzo duża różnica, gdyż zmiana poziomu hałasu o ok. 3dBA jest równoznaczna z podwojeniem mocy źródła hałasu. Należy również 
zaznaczyć, że praktyczna skuteczność ekranu akustycznego często nie przekracza 10dBA. Dalsze badania powinny skupić się na zaleceniach wyboru metody obliczeniowej w zależności od natężenia ruchu (jego wahań, struktury rodzajowej) oraz wskazaniu ograniczeń w stosowaniu metod pomiarowych opisanych w [2].

Badania zostaty zrealizowane w ramach realizacji Projektu ,Ochrona przed hałasem drogowym” finansowanego przez Narodowe Centrum Badań i Rozwoju oraz Generalną Dyrekcję Dróg Krajowych i Autostrad.

\section{Literatura}

[1] Rozporządzenie Ministra Środowiska z dnia 1 października 2012 r. zmieniające rozporządzenie w sprawie dopuszczalnych poziomów hałasu w środowisku. Dziennik Ustaw 2012, poz. 1109.

[2] Rozporządzenie Ministra Środowiska z dnia 16 czerwca 2011 r. w sprawie wymagań w zakresie prowadzenia pomiarów poziomów substancji lub energii w środowisku przez zarządzającego drogą, linią kolejową, linią tramwajową, lotniskiem lub portem. Dziennik Ustaw Nr 140, poz. 824.

[3] http://www.traxelektronik.pl/www/index.php \{dostęp 30.04.2016 r. \}.

[4] Spławińska M., Buczek P.: Problem zmienności natężeń ruchu na drogach krajowych i ich wpływ na poziom hałasu, Drogownictwo, nr 2/2015, s. 46-52.

[5] Woźniak K.: Wpływ dostępności do dróg na efektywność ochrony akustycznej otoczenia. Rozprawa doktorska, Politechnika Krakowska, Kraków, 2011.

[6] Radosz S.: Analiza wybranych parametrów ruchu i drogi w aspekcie ochrony akustycznej środowiska, Politechnika Krakowska, Praca doktorska Kraków 1984 r.

[7] Spławińska M.: Charakterystyki zmienności natężeń ruchu i ich wpływ na eksploatację wybranych obiektów drogowych. Rozprawa doktorska, Politechnika Krakowska, Kraków 2013.

[8] Spławińska M.: Określenie korzystnego czasowego zakresu pomiarów wyrywkowych do wyznaczania średniego dobowego ruchu w roku, Drogownictwo, nr 1/2015, s. 23-28.

\section{IMPACT OF TRAFFIC VARIABILITY FOR ASSESSMENT OF ANNOYANCE OF ROAD NOISE}

\section{S u m m a r y}

Time of the conducting of measurements (various period in the year and the day) determines the accuracy of estimating the level of noise. Therefore there is a need to define of uniform procedures for determining reliable values of traffic parameters (q,v, Hgv) for the calculation of $\mathrm{L}_{\mathrm{pAeq}}$. It is important particularly in relation to applying of the short-term method. The paper presents the possible impact of short-term measurements of traffic and noise to assess the level of road noise.

Keywords: noise, traffic, traffic fluctuations, traffic measurement

Przestano do redakcji: 07.06.2016 $r$.

Przyjęto do druku: $30.06 .2016 \mathrm{r}$.

DOI: $10.7862 / \mathrm{rb} .2016 .90$ 